\title{
JUSTICE, PEACE AND THE INTEGRITY OF CREATION: A PERSPECTIVE FROM THIRD WORLD THEOLOGIANS *
}

\author{
Emmanuel Kandusi \\ Centre for Contextual Hermeneutics
}

\begin{abstract}
The Ecumenical Association of Third World Theologians (EATWOT) was founded at an inaugural meeting in Dar es Salaam, Tanzania, from 5-12 August 1976, to provide a forum' for Third World Theologies. It is therefore a 'Fellowship of Third World Theologies, that would serve the church's mission in the world and witness to the new humanity in Christ, expressed in the struggle for a just society' (EATWOT Constitution). This article sets out the basic parameters of such Third World Theologies and then proceeds to relate them to the call for justice, peace, and the integrity of creation.
\end{abstract}

\section{Introduction}

I am very honoured to be with you at this crucial and interesting period of transformation towards a non-apartheid human South Africa.

Third World theologians are monitoring with keen interest what is taking place in your country and look forward to the maturity of a meaningful justice, peace and integrity of creation realized to all people without partiality. We all share the sentiments of the dreamer's dream 'We shall overcome some day', and we want that day to take place in our time. Theologians of this period are challenged to even further the struggle as our next generation will judge us by our contribution towards the struggle for a just society. Our praxis is vital; our historical respectability is in our hands and we can make it.

\footnotetext{
* This paper was presented at the Annual General Meeting of the Theological Society of Southern
} Africa in Pietermaritzburg, Natal, 24-26 July 1991. 


\section{Third World theologies}

As a representative of Third World theologians it is necessary that I should say something on the paradigm of Third World theologies as a prolegomenon to my comments on justice, peace and the integrity of creation.

Since the Reformation there has been no major theological paradigm which has made a bigger impact in human history than what has become known as Third World theologies. These are theologies which arise from the so-called Third World countries of Latin America; the Caribbean; Asia; the Pacific and Africa. These countries are characterized by a commonality in experience of 'the bitter fruit of oppression' (Frostin 1988:V). Fabella speaks of different layers of the term Third World 'which vary from the purely geographic (the South) to the socio-economic (poor, undeveloped) to political (non-aligned) and even theological (from the underside of history) (Fabella \& Torres 1983: xii). To amplify the concept of socioeconomic condition, Orlando Costas (Costas 1982:118) observes that

... seen from this perspective the Third World is the World of the sociological impoverished, oppressed and marginalized. By this definition the Third World is also present in the first and second worlds.

These are realized through Hispanics, blacks, the indigenous people in North America and the Aborigines of Australia.

All so-called Third World people put together 'constitute more than two-thirds of humankind' (Costas 1982:119). These are 'the victims of global injustice and exploitation, condemned to a history of poverty and marginalization' Costas 1982:119). But, Costas (1982:119) argues,

... in spite of all its historic humiliation and exploitation, its technological backwardness and dependence, the Third World is nevertheless a place of struggle, patience, courage and hope.

It is in this context that Third World theologians stress

... the countries (or people) of Third World have had similar experiences of which account should be taken in the task of theologizing.

addition).

(Torres \& Fabella 1978:271; bracketed is writer's

In the context Third World theologies struggle to answer our Lord's question (Mk 8:29):

But who do you say that I am? You are the Christ (in our Third Worldness understanding).

They join the Samaritans in testifying (Jn 4:42) (bracketed is writer's addition):

It is no longer because of your words (you missionaries, First World theologians) that we believe, for we have heard for ourselves and we know that this is indeed the saviour of the (Third) world (also) .

The struggle goes even further to call for cross-fertilization with other world theologies: 
We know you theologically. The question is, do you know us theologically? Would you like to know us theologically? Can you know us theologically?

(Mbiti 1969:16-17)

\section{A profile of Third World theologies}

We refer to Third World theologies and not theology because we realize the plurality of doing theology with commonalities and divergencies, yet sharing a common theological purpose in that they

... reflect on their Christian faith, and on the experiences this faith produces, in a particular context, with its particular characteristics.

(Abraham 1990:viii)

Looking into the profile of Third World theologies, the following aspects or characteristics are common in all of them: the use of the Bible; church tradition and experience; the interlocutors of theology; the comprehension of God; the analysis of conflict; contributions of social sciences; and theology as orthopraxis.

\section{1}

The use of the Bible, tradition and experience - is a crucial and basic source of Third World theologies. Third World experience or Sitz-im-Leben makes it imperative, however, for the Bible and Church traditions to be read in the social context of our struggle for humanity' (Kubi \& Torres 1979:193).

The experience of the Third World as a source of theology must be taken seriously'.

(Fabella \& Torres 1983:200).

The message of a holistic and total liberation - just and peaceful with respect to the whole creation - is seen as a central theme and message of the Bible.

\section{2}

The interlocutors of theology. Inspired by the concepts of Imago Dei, neighbour the poor, the sinners, the least of these, the hoi polloi, the inaugural scripture and address of our Lord Jesus Christ in Luke 4:18-19, Third World theologies have taken 'a preferential option for the poor', or as Gutierrez would say, the 'non-persons', 'the exploited classes, the marginalized races, all the despised cultures' (Gutierrez 1974:241). The 'epistemological privilege of the poor' (McAfee Brown 1978:61), hereby constituted, reflects on God vis-à-vis the experience of the poor in the struggle for liberation. It is a theology 'with the voice of the poor' (Bonino 1983:ix) as chief interlocutors.

\section{3}

The comprehension of God. The interlocutors of Third World theologies 'share the same faith as their oppressors, but they do not share the same economic, social or 
political life' (Gutierrez 1974:241). In that respect their comprehension of God is 'knowing on which side God is' (Fabella \& Torres 1985:190). It is a comprehension which moves them to struggle against Mammon and idolatry and discover the true God of liberation.

\section{4}

The analysis of conflict. The specific choice of the interlocutors of theology makes it imperative for the Third World theologies to address issues 'based on a conflictual perception of the social reality, affirming that there is a difference between the perspectives of the privileged "from above" and the poor "from below"' (Frostin 1988:8). This conflictual perception is so analyzed in economics (rich-poor); class studies (capitalist-proletariat); geography (North-South); sexism (male-female); ethnicity (e g white-black) and culture (dominant-dominated cultures) (Frostin 1988:8).

\section{5}

Contribution of social sciences. Frostin (1988:9; bracketed is writer's addition) observes that ' while in the past theological tools have usually come from philosophy, the social sciences are assuming this role in the new paradigm (Third World theologies). It is through social sciences that Third World theologies have been able to use in the process of social analysis, a crucial task in defining the interlocutors of theology and their dynamics in the struggle for full humanity.

\section{6}

Theology as orthopraxis. Third World theologies methodologically puts emphasis on the praxis of the theology done. It is a 'hermeneutical circulation' of 'theory and praxis where action forces the theologian to look at action again' (Frostin 1988:10). The focus of theology in this respect is not only orthodoxy, but orthopraxis.

\section{JPIC: A perspective from Third World theologies}

The publication of the World Council of Churches' Between the Flood and the Rainbow: Covenanting for JPIC raises serious concerns. These concerns include the scandal of poverty caused by an unjust international economic order, resulting in unnecessary deprivation and unfulfilled basic needs; deaths caused by malnutrition and undernourishment in the midst of plenty; violation of human rights leading to oppression such as detention without trial and even deaths; sins of sexism, in which one gender of the Imago Dei undermines another; the tenacity of racism seen in classical racism as in apartheid and structural racism, or in the forms of tribalism and nepotism; wars of destabilization; racial and religious wars; militalization which has resulted in the influx of refugees, internal and external. The disintegration of creation through pollution, deforestation, dumping of toxic waste in our natural resources, dangerous experiments which have resulted in manifold problems. JPIC 
addresses some of the specific problem such as greenhouse gases; ozone depletion; land degradation; deforestation; habitat destruction and species extinction; waste and global toxification; unlimited resource exploitation; use and misuse in biotechnology. These concerns are evidently subscribed to by Third World theologies. Moreover, Third World theologies know that those who suffer most bcause of the disintegration are the poor and oppressed. The interlocutors of theology as employed by Third World countries are the result of this experience. In that context I can boldly say that the whole exercise of JPIC is a result of a great contribution of Third World theologies and their counterpart progressive theologies of the Second and First Worlds.

Against this background TWTs call for justice and peace. It is a peace with and in justice. It is a call for shalom, a shalom which has three levels:

(a) shalom with God (Rom 5:1; Col 1:20)

(b) shalom with fellow human being (Eph 2) and

(c) shalom-activism (Eph 4:3; Heb 12:14).

In Third World theologies' and progressive theologies' concern for justice and peace is a praxis of faith. John Bennett (1975:11), in The Radical Imperative makes the following observation:

There is a Christian imperative to seek justice and peace. It is a mandate that requires a radical dealing with the problems of public life, the structures and institutions of society, the policies of governments and political movements for change. This radical imperative is a reflection of the love of God for all people, and human response to it is an expression of love for all neighbours.

The covenant for the Integrity of Creation takes the Third World people back to their roots. The Third World heritage is that of a symbiotic life with nature. This closeness with nature is a major reason for the sufferings of Third World people, due to the disintegration of creation. This is why the Third World has been crying for life, and this has been done even in theologizing: they join hands with 'the whole creation' (Rom 8:22), groaning for the holistic total liberation - now and thereafter. 


\section{BIBLIOGRAPHY}

Abraham, K C (ed), 1990. Third World Theologies. Orbis.

Bennett, J 1975. The Radical Imperative. Westminister.

Bonino, M 1983. Towards a Christian Political Ethics. SCM.

Costas, O 1978. Christ outside the gate. Orbis.

Fabella, V \& Torres, S (eds), 1983. Imuption of The Third World. Orbis.

Fabella, V \& Torres, S (eds), 1985. Doing theology in a divided World. Orbis.

Frostin, $\mathrm{P}$ 1988. Liberation Theology in Tanzania and South Africa. Lund University.

Gutierrez, G. Liberation Praxis and Christian Faith, in Rosino Gibellini (eds), Frontiers of Theology in Latin America.

Kubi, A \& Torres, S (eds), 1979. African Theology en route. Orbit.

Mbiti, J. Theological Importance and the Universality of the Church, in Anderson and Stransky (eds), Third World Theologies.

McAfee Brown, R 1978. Theology in a New Key: Responding to Liberation Themes. Westminister.

Torres, S \& Fabella, V (eds), 1978. The Emergent Gospel. Orbis. 